group, rather than the number of $\mathrm{OH}$ groups in the molecule.

5) The nutritive value of ricinolein is greatly improved by acetylation, but as to dioxyundecylin, dioxystearin and trioxystearin, the acetylation had little effect upon the nutritive value.

6) The improvement of the nutritive value of ricinolein by acetylation may be due to the formation of different products by breaking of its molecule.

7) Ricinolein was found to be better than its solid isomer, ricinoelaidin.

\title{
ON THE DISTRIBUTION OF A NEW THIOAMINO-ACID.
}

\author{
by Satoru OHDAkE. \\ (Abstract from the Original Paper)
}

(Received Sept 4th., 1926.)

In 1924, U. Suzuki, T. Mori and the author isolated a new sulphur compound from the alcoholic extract of yeast, and gave the empirical formula $\mathrm{C}_{11} \mathrm{H}_{15} \mathrm{NSO}_{3}$ to it. Boiled with diluted acids, it was hydrolysed easily to Adenin $\left(\mathrm{C}_{5} \mathrm{H}_{5} \mathrm{~N}_{5}\right)$ and a new thiosugar $\left(\mathrm{C}_{6} \mathrm{H}_{12} \mathrm{SO}_{4}\right)$ : so the authors concluded, this compound should be adenyl-thiomethyl-pentose. (U. Suzuki, S. Ohdake, and T. Mori:- The Journ. of the Agricultural Chemical Society of Japan. Vol. I No. 2 p. 127-136, 1924 and Biochemische Zeitschrift, B. 154, Heft. $3 / 6$ S. $278-289$, 1924.)

On studying further the alcoholic extract of yeast, the author isolated a new thioamino-acid in the following way:- The alcoholic extract of yeast was evaporated under diminished pressure to a syrupy consistence and dissolved in a little water. A concentrated tannin solution was then added, the precipitate thus formed, was collected, decomposed with baryta water and filtered. The filtrate, freed from an excess of baryta, was evaporated to a small volume, when the crystals of adenyl-thiomethyl-pentose separated out which were filtered off. To this filtrate, strong alcohol was added enough to make the alcoholic content of the mixture $80 \%$ by volume. The voluminous precipitate thus formed, was filtered by suction, and recrystallised several times from diluted alcohol. The crystals were found to be the mixture 
of leucin and a sulphur compound, but it was impossible to separate them by fractional crystallisation. It was therefore dissolved again in water, and the saturated solution of mercuric chloride was added. The sulphur compound alone, forming an insoluble salt with it, was precipitated and then decomposed with hydrogren sulphide. This treatment was repeated again and the resulted crystals were recrystallised from diluted alcohol. The yield of the purified compound was $0.6 \mathrm{~g}$. from $334,280 \mathrm{~kg}$. of fresh yeast.

The sulphur compound thus obtained having the emperical formula $\mathrm{C}_{5} \mathrm{H}_{11} \mathrm{SNO}_{2}$ is apparently a thioamino-acid as the analytical results of the free compound as well as of its derivatives show.

The purified compound is colourless and crystallises in thin monoclinic plates. Heated in a capillary, it melts at $271-272^{\circ} \mathrm{C}$ (uncorr.) with decomposition. It is easily soluble in water and in diluted alcohol, but insoluble in ether, benzene etc. Its specific rotatory power is $[\alpha]_{D}^{16}=-11.77^{\circ}$ in water. The aqueous solution of this compound gives a violet colour reaction with ninhydrin when warmed, but Millon's, Folin's, and biuret-reaction are all absent. With mercuric chloride, mercuric nitrate, and mercuric sulphate, it gives a white precipitate, but it is precipitated neither by phosphotungstic acid nor by picric acid. Even a boiling strong alkali does not split sulphur from this. compound in a form, detectable by sodium nitroprusside or by lead acetate, while both these reactions are positive, when it is fused with metallic sodium. In contrary to ethyl-cystein this sulphur compound is quite stable against a boiling strong alkali; giving neither ammonia nor ethylmercaptane. (Compare; Brenzinger :- Zeitschrift f. physiol. Chem. XVI. 563, 1892. Neuberg und Mayer :- Zeitschrift. f. physiol. Chem. 44, 489, 1905.)

The copper-salt $\mathrm{Cu}\left(\mathrm{C}_{5} \mathrm{H}_{10} \mathrm{SNO}_{2: 2}\right)_{2}$ forms light blue thin monoclinic plates which are somewhat soluble in boiling water but almost insoluble in the cold. Its derivative of $\alpha$-naphtyl-isocyanate $\mathrm{C}_{16} \mathrm{H}_{18} \mathrm{~N}_{2} \mathrm{SO}_{3}$ crystallises in white long needles, melting at $187^{\circ} \mathrm{C}$ (uncorr). It is almost insoluble in water, ether etc., but dissolves easily in alcohol. Its $\beta$-naphtalene-sulphoderivative $\mathrm{C}_{15} \mathrm{H}_{17} \mathrm{~S}_{2} \mathrm{NO}_{4}$ forms white needles, melting at $204^{\circ} \mathrm{C}$ (uncorr).

From these properties, the compound should be a new thioamino-acid having the formula $\left(\mathrm{C}_{3} \mathrm{H}_{7} \mathrm{~S}\right)-\mathrm{CHNH}_{2} \mathrm{COOH}$, besides the known sulphur compounds as cystin, cystein, and taurin etc. (S. Ohdake :- the Journ. of the Agricultural Chemical Soc. of Japan. Vol. I. No. 8. 1925, and Biochemische Zeitschrift. Bd. 161 Heft 4/6, 1925.)

Recently J. H. Muller isolated a new sulphur compound $\mathrm{C}_{5} \mathrm{H}_{11} \mathrm{SNO}_{2}$ from hydrolytic products of casein and egg-albumin. (J. H. Muller :- Journ. of Bact. VII p. 309-325. 1922 and Journ. of biol. chem. LVI. No. 1. 1923). 
The thioamino-acid, isolated by the author from the yeast-extract, has entirely the same properties with it. For the identification of these two substances, the author prepared the sulphur compound from casein according to Muller's mercuric method :-

Casein was hydrolysed with sulphuric acid, and neutralised with sodium hydroxide solution. To the filtrate, the sulphuric acid solution of mercuric sulphate was added, and the mixture was again neutralised with caustic soda. The precipitate was then extracted with hot $2 \%$ baryta water and filtered by suction. The filtrate freed from mercury and barium was evaporated to a small volume. Then the boiling saturated solution of mercuric chloride was added, using about $30 \mathrm{~g}$. of the reagent for each pound of protein. Standing about $30 \mathrm{hrs}$, the precipitate was collected and decomposed with hydrogen sulphide. The filtrate freed from mercury was evaporated to dryness in vacuo, and the residual substance was dissolved in water and treated with freshly prepared silver oxide. The silver chloride is filtered off and the excess of silver was removed with hydrogen sulphide. The filtrate from silver sulphide was evaporated to a small volume in vacuo. Finally, three or four volumes of hot alcohol were added to it, and on cooling, the sulphur compound separated as shining crystals. For the purpose of the purification, these crystals were dissolved in about ten times of hot water and treated with mercuric chloride again as described above. The yield of the pure compound was $1.12-1.74 \mathrm{~g}$. from each pound of casein.

As expected, the sulphur compound thus prepared from casein had entirely the same properties with that isolated from yeast-extract, except that its specific rotatory power was a little lower. It was proved that, the compound isolated by Muller was partially raceminized in the course of the extraction with hot baryta water.

The author, further, isolated the same thioamino-acid from the hydrolytic product of yeast-protein by the same treatment. It is clear, therefore, that the thioamino-acid isolated from yeast-extract must have been produced by the autolysis of yeast itself.

Although the existence of non-cystine-protein-sulphur has already been suspected often, it was still an open question if there exist one or more sulphur compounds in protein molecule other than cystin. The isolation of new sulphur compounds from protein should be a sole key to solve this problem.

To know the distribution of the "thioamino-acid," the author worked on the several kinds of protein by the same mercuric method as described above, and isolated the same thio-compound in a pure state though not quantitative. 
The yields of the "thioamino-acid" are as follows :-

$$
\begin{array}{lllllllllll}
\text { Casin } \quad \ldots & \ldots & \ldots & \ldots & \ldots & \ldots & \ldots & \ldots & \ldots & 0.25-0.39 & \% \\
\text { Egg-albumin } & \text { "Merck" } & \ldots & \ldots & \ldots & \ldots & 0.42 & \% \\
\text { Blood-fibrin } & \ldots & \ldots & \ldots & \ldots & \ldots & \ldots & \ldots & 0.26 & \% \\
\text { Beer-yeast } & \ldots & \ldots & \ldots & \ldots & \ldots & \ldots & \ldots & \ldots & 0.008 \% \\
\text { Protein from rice-bran } & \ldots & \ldots & \ldots & \ldots & 0.002 \% \\
\text { Protein from } & & \ldots & \ldots & \ldots
\end{array}
$$

From these results, the author has come to the general conclusion that the "thioamino-acid" is very widely distributed and is comparatively abundant in amimal proteins but scanty or even absent in vegetable proteins, especially in so-called reserve-proteins.

The author wishes to express his sincere thanks to Prof. Dr. U. Suzuki for his kind guidance.

\title{
ON THE SAPONIN OF ADZUKI BEAN.
}

\author{
By F. Takahashi and K. Shirahama.
}

(Received Aug. 26th , 1926.)

Isolation and properties : Pulverized Adzuki-bean was extracted with 95\% alcohol and the extraction was evaporated to dryness after the magnesium oxide had been added.

The residue was again extracted with alcohol and the saponin was precipitated with ether from the solution.

By the repeated precipitation as above, the pure saponin was obtained as a amorphous yellow powder.

The substance was soluble in water, alcohol or phenol and its aqueous solution foamed markedly on shaking and with concentrated sulphuric acid it gave a characteristic reddish purple coloration.

Elementary analysis gave the following results.

(1) $3.580 \mathrm{mg}$. saponin gave
(2) $4147 \mathrm{mg}$. saponin gave

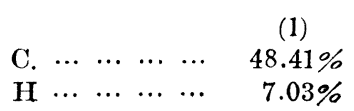

$6.355 \mathrm{mg} . \mathrm{CO}_{2}$ 2.250mg. $\mathrm{H}_{2} \mathrm{O}$ $7.318 \mathrm{mg} . \mathrm{CO}_{2}$
$2.540 \mathrm{mg} . \mathrm{H}_{2} \mathrm{O}$ 